\title{
Evaluation of flavonoids and diverse antioxidant activities of Sonchus arvensis
}

\author{
Rahmat Ali Khan
}

\begin{abstract}
Background: Sonchus arvensis is used in the treatment of various human aliments as a traditional medicine in Pakistan. In the study its various fractions are characterized for scavenging of diverse free radicals.

Results: Results of the present study revealed that various fractions of Sonchus arvensis significantly scavenged the free radicals (DPPH $\cdot$, ABTS $\cdot+, \cdot \mathrm{OH}$, superoxide), however its methanolic fraction is more potent than other fractions. Significant correlation was found between DPPH $\bullet$, ABTS $\bullet+$, superoxide radical and total antioxidant activity with total flavonoids and phenolics contents. Phytochmical analysis revealed the presence kaempferol, quercetin, orientin, rutin, hyperoside, catechin and myricetin.
\end{abstract}

Conclusion: From the present data it is concluded that various fractions of Sonchus arvensis significantly scavenged the free radical, which might be due the presence of polyphenolic constituent.

Keywords: Sonchus arvensis, Correlation, DPPH, Total antioxidant activity, HPLC

\section{Background}

Oxidation provides energy to living organisms for various metabolic processes. Normally a balance is present between amounts of free radicals produced in our body and antiradicals enzymatic and non enzymatic system to quench these and protect the body from their harmful effects [1]. Free radicals including superoxide anions, hydrogen peroxide and hydroxyl are extensively involved in oxidative damage at cellular level. Growing number of evidences suggest that reactive oxygen species (ROS) induced biochemical changes are decisive factors in various chronic human disease such as diabetes mellitus, cancer, atherosclerosis, arthritis, inflammation and neurodegeneration [2]. Human body has developed many mechanisms both enzymatic and nonenzymatic to eliminate ROS but not enough in severe oxidative stress conditions. Many studies have been carried out to investigate, that how to avoid the onset of oxidative diseases. The most studied system to fight against oxidative stress is to combat their level in body by supplying with greater amount of natural antioxidants, which can be attained by elevated use of vegetables and fruits. Natural antioxidants, particularly polyphenolics are safe and also

\footnotetext{
* Correspondence: Rahmatgul_81@yahoo.com

Department of Biotechnology, Faculty of Biological Sciences, University of Science and technology, Bannu 2800, KPK, Pakistan
}

bioactive. For that reason, in recent times, extensive studies have been conducted to identify plants with antiradical aptitude that may be used for human consumption [3]. The plant based therapeutics against oxidative stress induced diseases is the research of medicament of these days. The intake of fresh fruits, vegetables and tea rich in natural antioxidants has been connected with prevention of cancer and cardiovascular diseases [4]. The higher intake of plant foods correlates with lower risk of mortality from these diseases [5]. Approximately $60 \%$ of the commercially available anti-tumoral and antiinfective agents are of natural origin [6]. Polyphenols are the most significant constituents of plants for the antioxidant properties. The antiradical property of polyphenols is mostly because of their redox properties, which allow them to perform as reducing agents, singlet oxygen quenchers, metal chelators, hydrogen donors and reductants of ferryl hemoglobin [7-12]. Sonchus species are widely distributed throughout the Pakistan. Their aerial parts, popularly known as 'kucai', which remain the cheapest source of protein, vitamins, minerals and essential amino acids in the diet of many people, may be of great importance in helping to alleviate various human ailments such as hepatotoxicity [13], nephrotoxcity $[14,15]$, cardiotoxicity [16], astma [17], brain dysfunction [18], adrenal [19] and oxidative stress [20]. 


\section{Result and discussion}

Phytochemical characterization Total phenolics and flavonoids contents

Medicinal plant and their bioactive phenolic and flavonoids content play important role in scavenging of free radicals. Tables 1 and 2 represent the concentration of total phenolics and flavonoids contents in various fractions of Sonchus arvensis. Sonchus arvensis methanolic fraction showed greater concentration of total phenolics contents $(420 \pm 6.9)$ as compare to other fractions viz; chloroform (315 \pm 9.3$)$, ethyl acetate $(292 \pm 3.0)$ and nhexane $(131 \pm 2.3) \mathrm{mg}$ GAE/g respectively. Total flavonoid concentration are varied from $1.3 \pm 0.04$ to be $7.2 \pm 0.03$ with a descending order of methanol $>$ chloroform $>$ ethyl acetate $>\mathrm{n}$-hexane fraction. Methanolic fraction showed significantly $(P<0.01)$ high amount of total extractable phenolic and flavonoid compounds comparatively to chloroform, ethyl acetate and n-hexane fraction (Tables 1 and 2). Similar results were obtained by Khan et al. [21].

\section{HPLC quantification of flavonoids}

Various food supplements and medicinal plants possess bioactive polyphenolic flavonoids which effectively scavenging the reactive oxygen species because of their phenolics hydroxyl groups [22]. Sonchus arvensis powder was characterized for the presence of polyphenolic constituents, revealed the presence of orientin, rutin, kaempferol, myricetin, hyperuside, catechin and quercetin using integration peak-areas at $220 \mathrm{~nm}$ for quantification as shown in Figure 1. Various standard compounds were used to obtain calibration curves using least-squares linear regression. The linearity of all calibration curves was determined by calculating the correlation coefficients. Quantification of these compounds is shown in Table 3. Other researcher also reported similar results showing the presence of the bioactive constituent during chemical characterization of medicinal plants [23-26].

Table 1 Total flavonoid compounds and extraction yield in various fractions of Sonchus arvensis

\begin{tabular}{lll}
\hline $\begin{array}{l}\text { Sonchus arvensis } \\
\text { fraction }\end{array}$ & $\begin{array}{l}\text { Total flavonoids compounds } \\
\text { as rutin equivalent } \\
\text { (mg/g dry extract) }\end{array}$ & $\begin{array}{l}\text { \% yield } \\
\text { extraction }\end{array}$ \\
\hline Methanolic extract & $23.4 \pm 1.2^{\mathrm{d}}$ & $1.9 \pm 0.03^{\mathrm{c}}$ \\
\hline Chloroform fraction & $16.7 \pm 2.0^{c}$ & $1.0 \pm 0.04^{\mathrm{b}}$ \\
\hline Ethyl acetate fraction & $10.4 \pm 1.0^{\mathrm{b}}$ & $0.8 \pm 0.02^{\mathrm{b}}$ \\
\hline N-hexane fraction & $5.01 \pm 0.2^{\mathrm{a}}$ & $0.5 \pm 0.01^{\mathrm{a}}$ \\
\hline
\end{tabular}

Each value in the table is represented as Mean $\pm S D(n=3)$ Means not sharing the same letter are significantly different (LSD) at $P<0.01$ probability level in each column.
Table 2 Total phenolic compounds and extraction yield in various fractions of Sonchus arvensis

\begin{tabular}{lll}
\hline $\begin{array}{l}\text { Sonchus arvensis } \\
\text { fraction }\end{array}$ & $\begin{array}{l}\text { Total phenolic compounds } \\
\text { as } \mathbf{~ m g ~ g a l l i c ~ a c i d ~ e q u i v a l e n t ~} \\
\text { (GAE } \text { mg/g extract) }\end{array}$ & $\begin{array}{l}\text { \% yield } \\
\text { extraction }\end{array}$ \\
\hline Methanolic extract & $420 \pm 6.9^{\mathrm{c}}$ & $7.2 \pm 0.04^{\mathrm{d}}$ \\
\hline Chloroform fraction & $315 \pm 9.3^{\mathrm{b}}$ & $5.2 \pm 0.07^{\mathrm{c}}$ \\
\hline Ethyl acetate fraction & $292 \pm 3.0^{\mathrm{b}}$ & $3.2 \pm 0.05^{\mathrm{b}}$ \\
\hline N-hexane fraction & $131 \pm 2.3^{\mathrm{a}}$ & $1.3 \pm 0.03^{\mathrm{a}}$ \\
\hline
\end{tabular}

Each value in the table is represented as Mean $\pm S D(n=3)$ Means not sharing the same letter are significantly different (LSD) at $\mathrm{P}<0.01$ probability level in each column.

\section{Role of various fractions of Sonchus arvensis in scavenging of diverse free radicals}

Different free radical scavenging methods are used in this study to determine antioxidant efficacy of various Sonchus arvensis fractions.

Free radicals of 1, 1-diphenyl 1-2-picrylhydrazyl (DPPH) are widely used for screening of medicinal plants to investigate their antioxidant potential. The principle of this antioxidant assay is the capability of $\mathrm{DPPH}$, a stable free radical, to diminish the color in the presence of antioxidants. The deep purple color of DPPH radical is due to the presence of an odd electron in it [27]. When an electron donated by an antioxidant compound to DPPH, the DPPH is decolorized, this can easily be quantified by noting the change in absorbance at $515 \mathrm{~nm}$. The scavenging effect on DPPH radical was varied significantly by different fractions (Table 4). Oszmianski et al. [28] resulted similar antioxidant activities against DPPH. Various fractions of Sonchus arvensis revealed considerably different in their ABTS radical cation scavenging activities as shown in Table 4 dependent on solvent polarity might be due the prensence high molecular weight phenolics such as catechin, and rutin derivatives in addition to other flavonoids. Hagerman et al. [29] reported similar results in his experiment that the high molecular weight phenolics responsible for quenching of ABTS cation. The superoxide radical $\left(\mathrm{O}^{-2}\right)$ is produced by various biological reactions is very lethal free radical [30]. The hydroxyl radical generates toxic effects by interacting with DNA bases, proteins, and amino acids. The extracts reduce the photochemical reaction of NBT in the presence of riboflavin. NBT reduced into tetrazoinyl radical in the presence of $\left(\mathrm{O}^{-2}\right)$ that can transform to the formazan [30,31]. Results of the present study (Table 4) indicated that methanolic fraction (35 \pm 1.7 ) possess greater scavenging ability as chloroform $(45.7 \pm 2.2)$, ethyl acetate $(65.3 \pm 2.7)$ and $n$-hexane fractions $(89.2 \pm 3.9)$

The basic principle to assess the antioxidant capacity through phosphomolybdenum assay includes the reduction of Mo (VI) to Mo (V) by the plant extract possessing antioxidant compounds. In the present study 


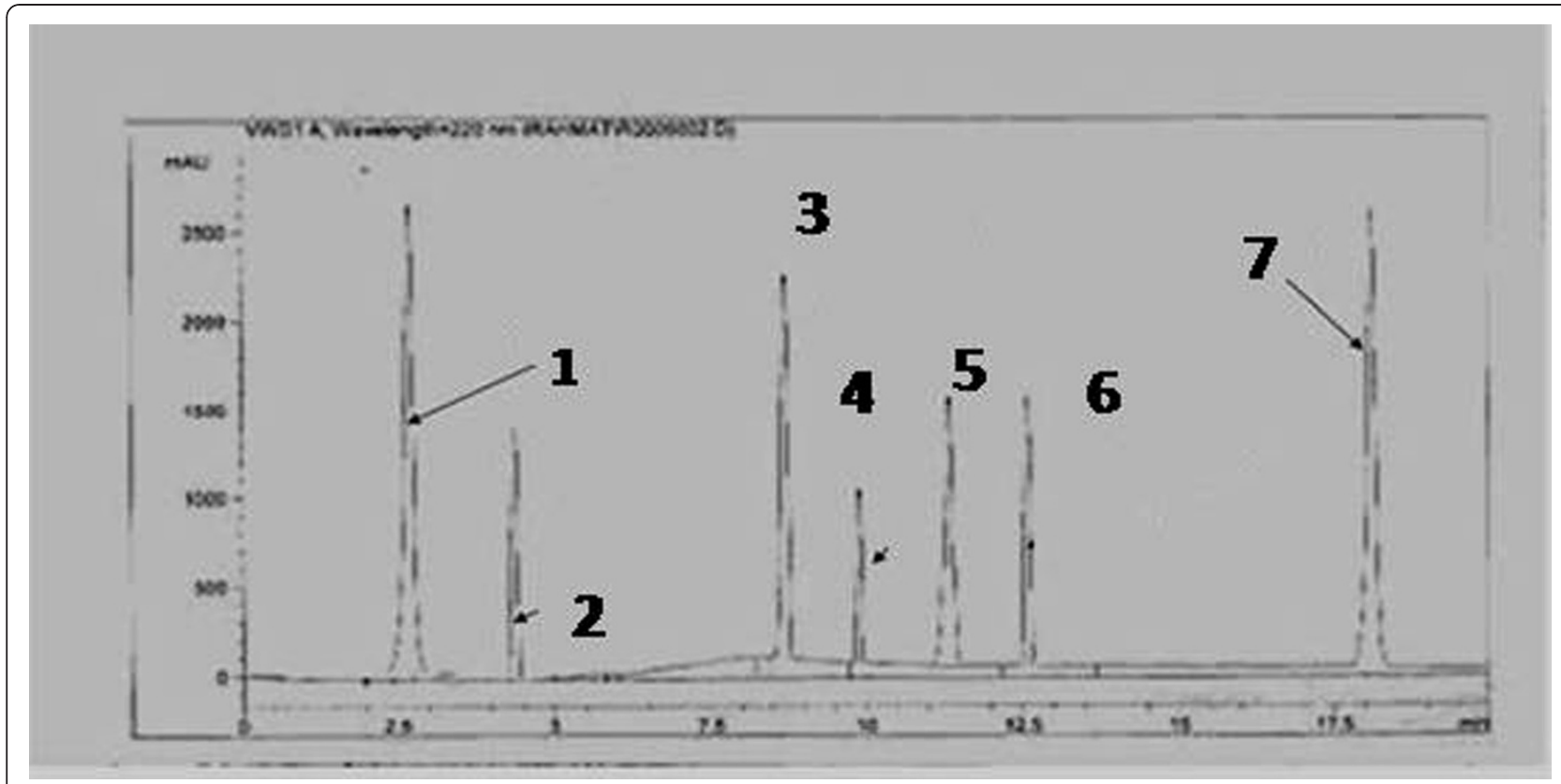

Figure $1 \mathrm{HPLC}$ fingerprints obtained from Sonchus arvensis eluted with mixtures trifluoroacetic acid and acetonitrile indicated the presence of six compounds 1.; (orientin), 2.; (hyperuside), 3.; (quercetin) 4.; (catechin) 5.; (rutin), 6.; (myricetin) and 7; (kaempferol).

addition of the various fractions of Sonchus arvensis showed reduction (Tables 4 and 5), suggested due the presence of effective antioxidants in various fractions as revealed in other study of literature [32]. Hydrogen peroxide non reactive, but sometimes it can be toxic to living cells, because in living cell it is converted into free radical called hydroxyl radicals $\left({ }^{\circ} \mathrm{OH}\right)$, react with biomolecules, cause tissue damage and cell death. Various fractions of Sonchus arvensis markedly scavenging of $\left({ }^{\circ} \mathrm{OH}\right)$ as shown in Table 4. Reduction of the iron ion is an indicator of electron-donating activity, which is an important mechanism of phenolic antioxidant action. Yellow color of test solution changes to various shades of green and blue depending upon the reducing power of each extract. Various fractions of Sonchus arvensis showed significant reduction in order methanolic < chloroform $<$ ethyl acetate $<$ n-hexane fraction due to the presence

\section{Table 3 HPLC quantification of Sonchus arvensis}

\begin{tabular}{lll}
\hline Retention time & Concentration $(\boldsymbol{\mu g} / \mathbf{m g}$ dry weight) & Compound \\
\hline 3.5 & $0.871 \pm 0.05$ & Orientin \\
\hline 4.0 & $0.455 \pm 0.03$ & Hyperuside \\
\hline 8.0 & $0.780 \pm 0.03$ & Quercetin \\
\hline 9.8 & $0.565 \pm 0.07$ & Catechin \\
\hline 11.2 & $0.457 \pm 0.02$ & Rutin \\
\hline 12.5 & $0.647 \pm 0.07$ & Myricetin \\
\hline 18.5 & $0.947 \pm 0.1$ & Kaempferol \\
\hline Mean \pm SD. & &
\end{tabular}

Mean \pm SD. of reductant (antioxidants) which causes the reduction of $\mathrm{Fe}^{3+} /$ Ferric cyanide complex to ferrous form.

\section{Correlations of antioxidant activities, phenolics and flavonoids content of Sonchus arvensis}

Table 6 revealed that there is a significant $(P<0.01)$ correlation between DPPH $\left(0.892^{\mathrm{b}}\right)$, reducing power $\left(0.823^{\mathrm{b}}\right)$, superoxide radical $\left(0.670^{\mathrm{c}}\right)$, hydrogen peroxide $\left(0.790^{\mathrm{b}}\right)$ and total antioxidant activity $\left(0.976^{\mathrm{a}}\right)$ and total phenolic contents in various fractions of extract while non significant correlation was observed of hydroxyl (0.303) and $\mathrm{ABTS}^{+}$radical (0.452) with total phenolic contents. Similar correlation is present between flavonoids contents and various free radicals used in this study. Present study also revealed that methanolic fraction is more potent as compared to other fractions $[33,34]$, which have shown that high total polyphenol content increases the antioxidant activity and proves a linear correlation between phenolics content and antioxidant activity. Methanolic fraction exhibited a significant correlation as was reported by Bortolomeazzi et al. [35] and Sahreen et al. [36].

\section{Materials and methods \\ Chemicals}

Nitroblue tetrazolium (NBT), $\beta$-nicotinamide adenine dinucleotide reduced ( $\beta$-NADH), 2-deoxy- D-ribose, linoleic acid, ammonium thiocyanate, $\beta$-carotene, 3(2-pyridyl)-5, 6 bis (4-phenylsulfonic acid)-1,2,4-triazine (ferrozine), Phenazine methosulphate (PMS), 2,2- 
Table 4 IC $_{50}$ of various fractions of Sonchus for diverse antioxidant systems

\begin{tabular}{lccr}
\hline $\begin{array}{l}\text { Sonchus arvensis } \\
\text { fraction }\end{array}$ & $\begin{array}{l}\text { Super oxide } \\
\text { radical } \\
\text { scavenging } \\
\text { assay }\end{array}$ & $\begin{array}{l}\text { DPPH radical } \\
\text { scavenging } \\
\text { assay activity }\end{array}$ & $\begin{array}{l}\text { ABTS }^{+} \text {radical } \\
\text { scavenging } \\
\text { assay }\end{array}$ \\
\hline Methanolic extract & $35 \pm 1.7^{\mathrm{a}}$ & $3.4 \pm 0.3^{\mathrm{a}}$ & $65.7 \pm 3.7^{\mathrm{a}}$ \\
\hline Chloroform fraction $^{\mathrm{a}}$ & $45.7 \pm 2.2^{\mathrm{b}}$ & $4.1 \pm 0.5^{\mathrm{a}}$ & $81.5 \pm 4.5^{\mathrm{b}}$ \\
\hline Ethyl acetate fraction & $65.3 \pm 2.7^{\mathrm{c}}$ & $6.7 \pm 0.2^{\mathrm{b}}$ & $100.7 \pm 7.5^{\mathrm{c}}$ \\
\hline N-hexane fraction & $89.2^{\mathrm{a}} \pm 3.9^{\mathrm{d}}$ & $10.1 \pm 0.8^{\mathrm{c}}$ & $123.5 \pm 5.8^{\mathrm{d}}$ \\
\hline Ascorbic acid & $69.6 \pm 4.1^{\mathrm{c}}$ & $3.9 \pm 0.7^{\mathrm{a}}$ & $86.3 \pm 4.5^{\mathrm{b}}$ \\
\hline
\end{tabular}

Each value in the table is represented as Mean $\pm S D(n=3)$ Means not sharing the same letter are significantly different $(\mathrm{LSD})$ at $\mathrm{P}<0.01$ probability level in each column.

diphenyl-1-picrylhydrazyl (DPPH), ethylenediamine tetra acetic acid (EDTA), rutin, ascorbic acid, gallic acid, potassium ferricyanide; trichloroacetic acid (TCA), thiobarbituric acids (TBA) were obtained from Sigma Aldrich Chemical Co. (USA). All other reagents were of analytical grade.

\section{Plant collection}

Sonchus arvensis was collected from District Bannu (Pakistan) during May 2011 at maturaty. Plants were identified and a voucher specimen (R0023) was submitted at Herbarium of University of Science and Technology Bannu, KPK, Pakistan. Whole plant (leaves, stem, flowers and seeds) were shades dried at room temperature for two weeks, chopped, ground mechanically of mesh size $1 \mathrm{~mm}$.

\section{Preparation of plant extracts}

$2 \mathrm{~kg}$ powder fine powder was socked in 4 liter of $80 \%$ hydroxyl methanol with random shaking for 7 days. After a week the extract was filtered through whatmann filter paper No. 45 and the filtrate was evaporated through rotary vacuum evaporator at $40^{\circ} \mathrm{C}$ to get

Table $\mathbf{5} \mathrm{IC}_{50}$ of various fractions of Sonchus arvensis for diverse antioxidant systems

\begin{tabular}{lllll}
\hline $\begin{array}{l}\text { Sonchus } \\
\text { arvensis } \\
\text { fraction }\end{array}$ & $\begin{array}{l}\text { Reducing } \\
\text { power }\end{array}$ & $\begin{array}{l}\text { Hydroxyl } \\
\text { scavenging } \\
\text { assay }\end{array}$ & $\begin{array}{l}\text { Hydrogen } \\
\text { peroxide } \\
\text { scavenging } \\
\text { assay }\end{array}$ & $\begin{array}{l}\text { Total } \\
\text { antioxidant } \\
\text { activity }\end{array}$ \\
\hline $\begin{array}{l}\text { Methanolic } \\
\text { extract }\end{array}$ & $53.1 \pm 2.7^{a}$ & $26.4 \pm 0.9^{a}$ & $86.4 \pm 7.1^{a}$ & $67.0 \pm 3.8^{a}$ \\
\hline $\begin{array}{l}\text { Chloroform } \\
\text { fraction }\end{array}$ & $81.3 \pm 3.2^{b}$ & $38.1 \pm 1.6^{b}$ & $90.2 \pm 8.5^{b}$ & $90.7 \pm 5.9^{b}$ \\
\hline $\begin{array}{l}\text { Ethyl acetate } \\
\text { fraction }\end{array}$ & $112.4 \pm 5.1^{c}$ & $43.1 \pm 3.9^{b}$ & $120.3 \pm 9.5^{b}$ & $110.5 \pm 7.0^{c}$ \\
\hline $\begin{array}{l}\text { N-hexane } \\
\text { fraction }\end{array}$ & $134.6 \pm 4.6^{\mathrm{d}}$ & $78.6 \pm 3.2^{\mathrm{c}}$ & $145.1 \pm 6.6^{\mathrm{c}}$ & $1322.21 \pm 8.4^{\mathrm{d}}$ \\
\hline Ascorbic acid & $55.7 \pm 2.0^{\mathrm{a}}$ & $24.2 \pm 2.65^{\mathrm{a}}$ & $90.3 \pm 7.5^{\mathrm{a}}$ & $70.3 \pm 3.5^{\mathrm{a}}$ \\
\hline
\end{tabular}

Each value in the table is represented as Mean \pm SD $(n=3)$ Means not sharing the same letter are significantly different $(\mathrm{LSD})$ at $\mathrm{P}<0.01$ probability level in each column.
Table 6 Correlations between the $\mathrm{IC}_{50}$ values of antioxidant activities, phenolics and flavonoids content of Sonchus arvensis

\begin{tabular}{|c|c|c|}
\hline \multirow[t]{2}{*}{ Assays $\left(I C_{50} \mu \mathrm{g} / \mathrm{ml}\right)$} & \multicolumn{2}{|c|}{ Correlations $\mathbf{R}^{2}$} \\
\hline & Phenolics & Flavonoids \\
\hline $\mathrm{DPPH}$ & $0.892^{b}$ & $0.981^{a}$ \\
\hline Reducing power & $0.823^{b}$ & $0.821^{\mathrm{b}}$ \\
\hline Super oxide radical scavenging & $0.670^{c}$ & $0.723^{c}$ \\
\hline Hydrogen peroxide scavenging assay & $0.790^{b}$ & $0.694^{c}$ \\
\hline Hydroxyl radical scavenging activity & 0.303 & 0.206 \\
\hline $\mathrm{ABTS}^{+}$radical scavenging assay & 0.452 & 0.347 \\
\hline Total antioxidant activity & $0.976^{a}$ & $0.712^{c}$ \\
\hline
\end{tabular}

Various fractions of Sonchus arvensis were used in the correlation. $a, b, c$ indicate significance at $P<0.05, P<0.01$ and $P<0.001$ respectively.

methanolic crude extracts (SME). The crude extract was suspended in water and fractionated by liquid: liquid partition with solvents of increasing polarity; starting from $\mathrm{n}$-hexane, ethyl acetate and chloroform. All the fractions were stored at $4^{\circ} \mathrm{C}$ for further phytochemical and in vitro investigations.

\section{Phytochemical investigation \\ Total phenolic contents}

Various fractions of Sonchus arvensis were used for determination of total phenolic content (TPC) using FolinCiocalteu reagent [37]. $400 \mu \mathrm{l}$ Folin-Ciocalteu reagents were mixed with $200 \mu \mathrm{l}$ of various fractions $(1.0 \mathrm{mg} / \mathrm{ml})$. The solution was incubated for $5-10 \mathrm{~min}$ at $25^{\circ} \mathrm{C}$ and mixed with $0.2 \mathrm{ml}$ of $7 \% \mathrm{Na}_{2} \mathrm{CO}_{3}$ solution and incubated for two $\mathrm{h} 25^{\circ} \mathrm{C}$ before taking the absorbance at $725 \mathrm{~nm}$. Gallic acid was used to plat standard calibration curve and total phenolics were calculated as per mg gallic acid (GAE) equivalents per gram of dried fraction $(\mathrm{mg} / \mathrm{g})$.

\section{Total flavonoid content}

Total flavonoids content was determined by using the protocol of Sakanaka et al. [38]. Briefly, $0.25 \mathrm{ml}$ of each fraction $(1 \mathrm{mg} / \mathrm{ml})$ and rutin standard solution (15-250 $\mu \mathrm{g} / \mathrm{ml}$ ) was mixed with $1.25 \mathrm{ml}$ of distilled water in a test tube, followed by addition of $75 \mu \mathrm{l}$ of a $5 \%(\mathrm{w} / \mathrm{v})$ sodium nitrite solution. After $6 \mathrm{~min}, 150 \mu \mathrm{l}$ of $10 \%(\mathrm{w} / \mathrm{v}$ ) aluminum chloride solution was added, and the mixture was allowed to stand for a further 5 min before $0.5 \mathrm{ml}$ of $1 \mathrm{M} \mathrm{NaOH}$ was added. The mixture was made up to 2.5 $\mathrm{ml}$ with distilled water and mixed well. The absorbance was measured immediately at $510 \mathrm{~nm}$. The results of samples were expressed as $\mathrm{mg}$ of rutin equivalents of total extractable compounds.

\section{High performance liquid chromatography}

For determination bioactive constituents responsible for pharmacological activities $1 \mathrm{~g}$ fine powder of Sonchus 
arvensis was extracted with $25 \%$ hydrochloric acid and methanol for $1 \mathrm{~h}$. The extract was diluted with methanol. $10 \mu \mathrm{l}$ samples were injected into the HPLC apparatus. Separation was carried out through column $(5 \mu \mathrm{m}$; $4.6 \times 150 \mathrm{~mm}$, Agilent) with UV-vis detector. Solvent A (0.05\% trifluoroacetic acid) and solvent B $(0.038 \%$ trifluoroacetic acid in $83 \%$ acetonitrile (v/v) with the following gradient: $0-5 \mathrm{~min}, 15 \% \mathrm{~B}$ in $\mathrm{A}, 5-10 \mathrm{~min}, 70 \% \mathrm{~B}$ in $\mathrm{A}, 10-15 \mathrm{~min}, 70 \% \mathrm{~B}$ in $\mathrm{A}$ are used for separation. The flow rate was $1 \mathrm{ml} / \mathrm{min}$ and injection volume was $10 \mu$ l. Six different standards compounds (myricetin, catechin, kaempferol, quercetin orientin, hyperuside, and rutin) were run for comparable detection and optimized. The calibration curves were defined for each compound in the range of sample quantity $0.02-0.5 \mu \mathrm{g}$. All samples were assayed in triplicate. All quantitative data were explained by analyst software.

\section{Pharmacological assessment}

Various fractions of Sonchus arvensis were characterized for scavenging of various free radicals. All these methods are expressed with IC50.

\section{Scavenging of diphenylpicrylhydrazyl (DPPH) radical}

DPPH free radical scvanging activity of various fractions of Sonchus arvensis was achived using the standard protocol of Gyamfi et al. [39]. A stock solution of DPPH was made by dissolving $2.4 \mathrm{mg} \mathrm{DPPH}$ in $100 \mathrm{ml}$ of methanol and diluted after achieving an absorbance of $0.980( \pm 0.02)$ at $517 \mathrm{~nm} .500 \mu \mathrm{l}$ of $\mathrm{DPPH}$ solution was mixed with $500 \mu \mathrm{l}$ of each fraction $(50-250 \mu \mathrm{g} / \mathrm{ml})$ and incubated for $30 \mathrm{~min}$ in dark after vigorous shacking. Absorbance was recorded at $517 \mathrm{~nm}$ and DPPH scavenging activity of various fractions was calculated by the following equation: Percentage Inhibition $(\%)=[(\mathrm{Ab}-$ sorbance of control-Absorbance of sample) / (Absorbance of control) $] \times 100 . \mathrm{IC}_{50}$ values obtained as to determine the $50 \%$ inhibition of DPPH radicals. Ascorbic acid was used as standards.

\section{ABTS radical scavenging}

To assess the ABTS free radical scavenging stock solution was prepared by mixing equal volumes of $7 \mathrm{mM}$ ABTS solution and $2.45 \mathrm{mM}$ potassium persulfate solution [40]. The mixture was incubated at room temperature in the dark for $12 \mathrm{~h}$ to yield a dark-colored solution containing $\mathrm{ABTS}^{\circ+}$ radicals and diluted for an initial absorbance of about $0.700( \pm 0.02)$ at $745 \mathrm{~nm} .300$ $\mu \mathrm{l}$ of each fraction $(25-250 \mu \mathrm{g} / \mathrm{ml})$ was mixed with 2.7 $\mathrm{ml}$ of ABTS working solution and measured absorbance exactly $1 \mathrm{~min}$ after mixing the solution. The final absorbance was noted up to $6 \mathrm{~min}$ and data for each assay was recorded in triplicate. Ascorbic acid was used as positive controls. The scavenging activity was estimated based on the percentage of ABTS radicals scavenged by the following formula: \% scavenging $=\left(A_{0}-A_{S} / A_{0}\right) \times$ 100 , Where $A_{0}$ is absorption of control, $A_{S}$ is absorption of tested extract solution.

\section{Superoxide radical scavenging}

The riboflavin-light-NBT system was employed to assay the superoxide radical [31]. The reaction mixture consisted of $500 \mu \mathrm{l}$ of $50 \mathrm{mM}$ phosphate buffer ( $\mathrm{pH} 7.6)$, $300 \mu \mathrm{l}$ of $50 \mathrm{mM}$ riboflavin, $250 \mu \mathrm{l}$ of $20 \mathrm{mM}$ PMS and $100 \mu \mathrm{l}$ of $0.5 \mathrm{mM}$ NBT before adding up of $1.0 \mathrm{ml}$ of various fractions. Reaction was initiated by illuminating the above solution using a fluorescent lamp. After placing there for $20 \mathrm{~min}$, the absorbance was recorded at $560 \mathrm{~nm}$. The percentage of scavenging superoxide anion generation was calculated as: Percentage inhibition (\%) = (1- sample absorbance/control absorbance) $\times 100$.

\section{Total antioxidant capacity}

Reduction of phosphomolybdenum was calculated to determine the total antioxidant capacity of different samples by adapting the method described by Prieto et al. [41]. $100 \mu \mathrm{l}$ of each fraction was mixed with the reagent solution $(1.0 \mathrm{ml})$ consisting of phosphate buffer, $0.6 \mathrm{M}$ $\mathrm{H}_{2} \mathrm{SO}_{4}, 28.0 \mathrm{mM}$ sodium molybdate and $4.0 \mathrm{mM}$ ammonium molybdate. The mixture was placed in a water bath at $95^{\circ} \mathrm{C}$ for $90 \mathrm{~min}$. After cooling to room temperature, the absorbance was taken at $765 \mathrm{~nm}$. A standard of ascorbic acid was employed. Total antioxidant scavenging capacity was calculated as: Total Antioxidant capacity $(\%)=[$ (Abs. of control-Abs. of sample) / (Abs. of control] $\times 100$.

\section{Hydrogen peroxide scavenging}

The scavenging capacity for hydrogen peroxide was measured according to the method [42]. A solution of hydrogen peroxide $(2 \mathrm{mM})$ was prepared in $50 \mathrm{mM}$ phosphate buffer ( $\mathrm{pH}$ 7.4). Hydrogen peroxide concentration was determined spectrophotometrically at 230 $\mathrm{nm}$ absorption using the molar extinction coefficient for $\mathrm{H}_{2} \mathrm{O}_{2}$ of $81 \mathrm{~mol}^{-1} \mathrm{~cm}^{-1} .0 .1 \mathrm{ml}$ of various fractions (25$250 \mu \mathrm{g} / \mathrm{ml}$ in respective solvents), ascorbic acid was transferred into the test tubes and their volumes were made up to $0.4 \mathrm{ml}$ with $50 \mathrm{mM}$ phosphate buffer ( $\mathrm{pH}$ 7.4) or solvent (methanol). After addition of $0.6 \mathrm{ml}$ hydrogen peroxide solution, tubes were vortexed and absorbance of the hydrogen peroxide at $230 \mathrm{~nm}$ was determined after $10 \mathrm{~min}$, against a blank. $50 \mathrm{mM}$ phosphate buffer without hydrogen peroxide was used as blank. Hydrogen peroxide scavenging ability (in triplicate) was calculated by the formula:\% scavenging $=(1-\mathrm{Ae} / \mathrm{Ao}) \times$ 100 , where Ao is the absorbance without sample, and Ae is absorbance with sample. 


\section{Hydroxyl radical scavenging}

The effect of extracts on hydroxyl radicals was assayed by using the deoxyribose method [43]. 2-Deoxyribose is degraded on exposure to hydroxyl radicals generated by Fenton's reaction. Each fraction and ascorbic acid (ASA) was prepared in methanol. The reaction mixture contained $450 \mu \mathrm{l}$ of $0.2 \mathrm{M}$ sodium phosphate buffer $(\mathrm{pH}$ 7.0), $150 \mu \mathrm{l}$ of $10 \mathrm{mM}$ 2-deoxyribose, $150 \mu \mathrm{l}$ of $10 \mathrm{mM}$ $\mathrm{FeSO}_{4}$-EDTA, $150 \mu \mathrm{l}$ of $10 \mathrm{mM} \mathrm{H}_{2} \mathrm{O}_{2}, 525 \mu \mathrm{l}$ of $\mathrm{H}_{2} \mathrm{O}$, and $75 \mu \mathrm{l}$ of sample solution $(0.050-0.250 \mathrm{mg} / \mathrm{ml}$ in respective solvents). The reaction was started by the addition of $\mathrm{H}_{2} \mathrm{O}_{2}$. After incubation at $37^{\circ} \mathrm{C}$ for $4 \mathrm{~h}$, the reaction was stopped by adding $750 \mu \mathrm{l}$ of $2.8 \%$ trichloroacetic acid and $750 \mu \mathrm{l}$ of $1 \%$ TBA in $50 \mathrm{mM}$ $\mathrm{NaOH}$, the solution was boiled for $10 \mathrm{~min}$, and then cooled in water. The absorbance of the solution was measured at $520 \mathrm{~nm}$. Ascorbic acid $(0.05-0.250 \mathrm{mg} / \mathrm{ml})$ was used as a positive control. The ability to scavenge the hydroxyl radical was calculated using the following equation: $\%$ Hydroxyl radicals scavenging activity $=(1-$ absorbance of sample / absorbance of control) $\times 100$.

\section{Reducing power}

The ability to reduce Fe (III) to Fe (II) was obtained by the procedure stated [44] with some modifications. Extract solution of $1 \mathrm{ml}$ was mixed with $2.5 \mathrm{ml}$ of $0.2 \mathrm{M}$ phosphate buffer ( $\mathrm{pH}$ 6.6) and $2.5 \mathrm{ml}$ of $1 \%$ potassium ferricyanide and then mixture was placed at $50^{\circ} \mathrm{C}$ for 20 min. $2.5 \mathrm{ml}$ of $10 \%$ TCA was added to the solution and centrifuged at $3000 \mathrm{rpm}$ for $10 \mathrm{~min}$. A $2.5 \mathrm{ml}$ of supernatant was mixed with $2.5 \mathrm{ml}$ of distilled water and 500 $\mu \mathrm{l}$ of $1 \% \mathrm{FeCl}_{3}$ and absorbance was noted at $700 \mathrm{~nm}$. Increase in reducing power of extracts was deduced by an increase in absorbance. Ascorbic acid was used as standard in this experiment.

\section{Statistical analysis}

Readings for all scavenging assays were taken in triplicate. Graph Pad Prism 5 software was used to calculate the IC50 values. Standard deviation and ANOVA was employed to investigate the differences among IC50 of different fractions for different antiradical assays. Pearson correlation coefficient for phenolic and flavonoids was also employed. All the assays findings were subjected to Student's t test $(\mathrm{P}<0.05 ; \mathrm{P}<0.01)$ to find their significance.

\section{Conclusion}

Various fractions of Sonchus arvensis revealed significant afficecy in scavenging of free radicals due the presence of poly phenolics compounds as reported via HPLC. The extract can be utilized as an effective and safe antioxidant source, as ethnomedicine and on a commercial basis for the development of drugs.

\section{Competing interests}

The authors declare that they have no competing interests.

\section{Authors' contributions}

RAK made significant contribution to acquisition of data, analysis, drafting of the manuscript, conception and design. Author read and approved the final manuscript.

\section{Acknowledgement}

We would like to thank Higher Education Commission (HEC) Government of Pakistan for providing support to this project.

Received: 19 August 2012 Accepted: 11 October 2012

Published: 29 October 2012

\section{References}

1. Shirwaikar A, Shirwaikar A, Rajendran K, Punitha ISR: In vitro antioxidant studies on the benzyl tetra tsoquinoline alkaloid berberine. Biol Pharm Bull 2006, 29:1906-1910.

2. Soni H, Pandey H, Phatak AK, Nayak G, Singhai AK, Parihar A, Singh V, Rathur AS: Evaluation of antioxidant potential of hydro alcoholic extract of leaves of Coleus aromaticus. Adv Pharmacol Toxicol 2009, 10(1):75-82.

3. Jain S, Gupta A, Malviya N, Suhur H: Comparative antioxidant potential screening of polyherbal formulations. Adv Pharmocol Toxicol 2006, 10(1):101-110.

4. Willcox JK, Ash SL, Catignani GL: Antioxidants and prevention of chronic disease. Food Sci Nutr 2004, 44:275-295.

5. Johnson IT: Antioxidants in food. Cambridge: Woodhead Publishing Ltd; 2001.

6. Cragg GM, Newman DJ, Weiss RB: Coral reefs, forests, and thermal vents: the worldwide exploration of nature for novel antitumor agents. Semin Oncol 1997, 24:156-163.

7. Rice-Evans C, Miller N, Bolwell P, Bramley P, Pridham J: The relative antioxidant activities of plant-derived polyphenolic flavonoids. Free Radic Res 1995, 22:375-383.

8. Rice-Evans C, Miller N, Paganga G: Antioxidant properties of phenolic compounds. Trends Plant Sci 1997, 2:152-159.

9. Prior RL, Wu X, Schaich K: Standardized methods for the determination of phenolics in foods, and dietary supplements. J Agric Food Chem 2005, 53:4290-4302.

10. Lopez D, Pavelkova M, Gallova L, Simonetti P, Gardana C, Lojek A, Loaiza R, Mltjavila MT: Dealcoholized red and white wines decrease oxidative stress associated with inflammation in rats. Br J Nutr 2007, 98:611-619.

11. Ciz M, Pavelkova M, Gallova L, Kralova J, Kubala L, Lojek A: The influence of wine polyphenols on reactive oxygen and nitrogen species production by murine macrophages RAW 264.7. Physiol Res 2008, 57:393-402.

12. Gebick L, Banasiak E: Role of medicinal in oxidative stress. Acta Biochim Pol 2009, 56:509-513.

13. Khan RA, Khan MR, Sahreen S, Naseer AS: Hepatoprotective activity of Sonchus asper against carbon tetrachloride-induced injuries in male rats: a randomized controlled trial. BMC Compl Alter Med 2012, 12:90.

14. Khan RA, Khan MR, Sahreen S, Shah NA: Amelioration of kidney function markers by Sonchus asper butanolic extract against $\mathrm{KBrO}_{3}$-induced toxicity in rat. J Med Plants Res 2012, 6(7):1224-1228.

15. Khan RA, Khan MR, Sahreen S, Jan S, Bokhari J, Rashid U: Potassium bromate $\left(\mathrm{KBrO}_{3}\right)$ induced nephrotoxicity: protective effects of $\mathrm{n}$-hexane extract of Sonchus asper. J Med Plants Res 2012, 5(25):6055-6060.

16. Khan MR, Haroon J, Khan RA, Bokhari J, Rashid U: Prevention of $\mathrm{KBrO}_{3}$-induced cardiotoxicity by Sonchus asper in rat. $J$ Med Plants Res 2012, 5(12):2514-2520

17. Khan RA, Khan MR, Sahreen S: Protective effect of Sonchus asper extracts against experimentally-induced lung injuries in rats: a novel study. Exp Toxicologic Pathol 2011, doi:doi:10.1016/j.etp.2011.01.007.

18. Khan RA, Khan MR, Sahreen S: Brain antioxidant markers, cognitive performance and acetyl cholinesterase activity of rat: efficiency of Sonchus asper. Behav Brain Funct 2012, 8:21.

19. Khan RA, Khan MR, Sahreen S, Jan S, Bokhari J, Rashid U: Prevention of $\mathrm{CCl}_{4}$ induced adrenal oxidative stress in rat by Sonchus asper. J Med Plants Res 2011, 5(15):3347-3350 
20. Khan RA, Khan MR, Sahreen S, Ahmed M: Evaluation of phenolic contents and antioxidant activity of various solvent extracts of Sonchus asper (L.) Hill. Chem Central J 2012, 6:12.

21. Khan RA, Khan MR, Sahreen S: Assessment of flavonoids contents and in vitro antioxidant activity of Launaea procumbens Chemistry Central Journal. Chem Central J 2012, 6:43.

22. Cao G, Sofic E, Prior RL: Antioxidant and pro-oxidant behavior of flavonoids: structure activity relationships. Free Rad Biol Med 2009, 22:749-760

23. Zu Y, Fu Y, Liu W, Hou C, Kong Y: Simultaneous determination of four flavonoids in Pigeonpea [Cajanus cajan (L.) Millsp.] leaves using RP-LC-DAD. Chromatographia 2006, 63:9-10.

24. Wijeratne SS, Abou-Zaid MM, Shahidi F: Antioxidant polyphenols in almond and its coproducts. JAgric Food Chem 2006, 54:312-318.

25. Liyana-Pathirana CM, Shahidi F: Importance of insoluble-bound phenolics to antioxidant properties of wheat. J Agric Food Chem 2006, 54:1256-1264.

26. Shahidi F, Alasalvar C, Liyana-Pathirana CM: Antioxidant phytochemicals in hazelnut kernel (Corylus avellana L.) and hazelnut byproduct. J Agric Food Chem 2007, 55:1212-1220.

27. Brand-Williams W, Cuvelier ME, Berset C: Use of free radical method to evaluate antioxidant activity. Leben smittel Wissen schaftund Tech 1995, 28:25-30.

28. Oszmianski J, Wolniak M, Wojdylo A, Wawer I: Comparative study of polyphenolic content and antiradical activity of cloudy and clear apple juices. J Sci Food Agric 2007, 87:573-579.

29. Hagerman AE, Riedl KM, Jones GA, Sovik KN, Ritchard NT, Hartzfeld PW: High molecular weight plant polyphenolics (tannins) as biological antioxidants. J Agric Food Chem 1998, 46:1887-1892.

30. Sahreen S, Khan MR, Khan RA: Evaluation of antioxidant activities of various solvent extracts of Carissa opaca fruits. Food Chem 2010, 122:1205-1211.

31. Nishikimi M, Rao NA, Yagi K: The occurence of superoxide anion in the reaction of reduced phenazine methosulfate and molecular oxygen. Biochem Biophys Res Commun 1972, 46:849-854.

32. Khan RA: Protective effect of Launaea procumbens (L.) on lungs against $\mathrm{CCl}_{4}$ induced toxicity in rat. BMC Compl Alter Med 2012, 12:133.

33. Gorinstein S, Martin-Belloso O, Katrich E, Lojek A, Ciz M, Gligelmo-Miguel N Comparison of the contents of the main biochemical compounds and the antioxidant activity of some Spanish olive oils as determined by four different radical scavenging tests. J Nut Biochem 2003, 14:154-159.

34. Maisuthisakul P, Suttajit M, Pongsawatmanit R: Assessment of phenolic content and free radical-scavenging capacity of some Thai indigenous plants. Food Chem 2007, 100:1409-1418.

35. Bortolomeazzi R, Sebastianutto N, Toniolo R, Pizzariello A: Comparative evaluation of the antioxidant capacity of smoke flavouring phenols by crocin bleaching inhibition, DPPH radical scavenging and oxidation potential. Food Chem 2007, 100:1481-1489.

36. Sahreen S, Khan MR, Khan RA: Phenolic compounds and antioxidant activities of Rumex hastatus D. Don. Leaves. J Med Plants Res, 5(13):2755-2765

37. Singleton $V L$, Rossi JA: Colorimetry of total phenolics with phosphomolybdic-phosphotungstic acid reagents. Am J Enol Viticulture 1996, 16:144-153.

38. Sakanaka S, Tachibana Y, Okada Y: Preparation and antioxidant properties of extracts of Japanese persimmon leaf tea (kakinoha-cha). Food Chem 2005, 9:569-575.

39. Gyamfi MA, Yonamine M, Aniya Y: Free radical scavenging activity of medicinal herb of Ghana: Thonningia sanguinea on experimentally induced liver injuries. General Pharmacol 1999, 32:661-667.

40. Re R, Pellegrini N, Proteggente A, Pannala A, Yong M, Rice-Evas C: Antioxidant activity applying an improved ABTS radical cation decoloursation assay. Free Rad Biol Med 1999, 26:1231-1237.

41. Prieto P, Pineda M, Aguilar M: Spectophotometric quantitation of antioxidant capacity through the formation of a phosphomolybdenum complex: Specific application to the determination of vitamin E. Anal of Biochem 2005, 269:337-341.

42. Ruch RJ, Cheng SJ, Klaunig JE: Prevention of cytotoxicity and inhibition of intercellular communication by antioxidant catechin isolated from Chinese green tea. Carcinogenesis 1989, 10:1003-1008.
43. Nagai T, Myoda T, Nagashima T: Antioxidative activities of water extract and ethanol extract from field horsetail (tsukushi) Equisetum arvense L. Food Chem 2005, 91:389-394.

44. Dinis TCP, Madeira VMC, Almeida LM: Action of phenolic derivatives (acetaminophen, salicylate and 5-aminosalicylate) as inhibitors of membrane lipid peroxidation and as peroxyl radical scavengers. Arch Biochem Biophys 1994, 315:161-169.

doi:10.1186/1752-153X-6-126

Cite this article as: Khan: Evaluation of flavonoids and diverse antioxidant activities of Sonchus arvensis. Chemistry Central Journal 2012 6:126.

\section{Publish with ChemistryCentral and every scientist can read your work free of charge \\ "Open access provides opportunities to our colleagues in other parts of the globe, by allowing anyone to view the content free of charge." \\ W. Jeffery Hurst, The Hershey Company.}

- available free of charge to the entire scientific community

- peer reviewed and published immediately upon acceptance

- cited in PubMed and archived on PubMed Central

- yours - you keep the copyright

Submit your manuscript here:

http://www.chemistrycentral.com/manuscript/<smiles>c1ccccc1</smiles>

Chemistry Central 